NBER WORKING PAPFR SERIFS

\begin{abstract}
ENERGY AND RESOURCE ALIOCATION: A DYNAMIC MODEL OF THE "DUTCH DISEASE"
\end{abstract}

\author{
Michael Bruno \\ Jeffrey Sachs \\ Working Paper No. 952 \\ NATIONAL BUREAUT OF ECONOMIC RESEARCH \\ 1050 Massachusetts Avenue \\ Cambridge MA 02138 \\ February 1982
}

This paper was presented at the Conference on Unemployment, Newnham College, Cambridge, July 1981, under the original title "Input Price Shocks and the Slowdown in Economic Growth, Part II." The paper is part of a joint study of the authors on the macroeconomic effects of supply shocks. We thank Mr. Louis Dicks-Mireaux for very able research assistance. Support from the National Science Foundation is gratefully acknowledged. The research reported here is part of the NBER's research program in International studies. Any opinions expressed are those of the authors and not those of the National Bureau of Economic Research. 


\begin{abstract}
$\underline{\text { ABSTRACT }}$
It is well known that a domestic resource discovery gives rise to wealth effects that cause a squeeze of the tradeable good sector of an open economy. The decline of the manufacturing sector following an energy discovery has been termed the "Dutch disease," and has been investigated in many recent studies. Our model extends the principally static analyses to date by allowing for: (1) short-run capital specificity and long-run capital mobility; (2) international capital flows; and (3) far-sighted intertemporal optimizing behavior by households and firms. The model is solved by numerical simulation.
\end{abstract}

Michael Bruno

Department of Economics

Hebrew University

Je ruselam, Is rael
Jeffrey Sachs

Department of Economics Harvard University Cambridge, MA 02138

(617)868-3927 
The rise in energy prices in the $1970^{\circ} \mathrm{s}$ upset the sectoral allocation of resources as well as the overall macroeconomic balance of supply and demand. Most obviously, energy-intensive industries such as steel or aluminum were hard hit, while sectors producing energy substitutes and primary energy (coal, gas, etc.) flourished. Less obvious, though probably more pervasive were the sectoral demand shifts caused by the reallocation of wealth following the OPEC shocks. Energy-poor countries (e.g. Japan) scaled back domestic absorption sharply in the face of higher oil import bills, while spending in the oilexporting countries boomed. Shifts in overall absorption have differential effects on the production of traded and non-traded goods, with a wealth increase raising non-traded good production and squeezing the traded-good sector. The squeeze of the tradeables sector in such a context has become known as the "Dutch disease," and is the subject of this analysis.

Many recent studies $[1,3,4,6,7,9]$ have investigated the consequences of an oil discovery or oil price increase for resource allocation, but the analyses to date have been incomplete. The effects on the traded and non-traded goods sectors are inherently dynamic, though most models have been static, either focussing on the short run or long run. A rise in wealth shifts demand towards the non-traded good sector, and sets in train a process of capital accumulation in that sector and decumulation in the other. Moreover, there are likely to be current account imbalances over time, first as the economy borrows from abroad to finance capital expenditures in the oil sector, and later as the economy lends abroad out of oil earnings. 
Thus, a complete theoretical model should allow for: (1) short-run capital specificity, and long-run capital mobility between sectors; (2) capital accumulation in the aggregate; (3) international capital mobility; and (4) far-sighted behavior by firms and households (in their investment, consumption and savings decisions). Bruno [1] provides for these factors in a two-period analytical model, and this paper complements that analysis by extending it to the infinitehorizon case. This extension allows for a realistic assessment of empirical magnitudes along the adjustment path of the economy. This substantial benefit comes at some cost: the model is no longer analytically tractable and must be solved by numerical alogorithms, as we describe below.

The model employed here is a direct extension of the framework described by us elsewhere in this volume [2]. In addition to exogenous energy production, firms in the traded and non-traded goods sectors produce output according to two-level CES production functions, combining value-added with intermediate inputs. Capital is assumed to be costly to adjust, so that determinate investment demand equations may be derived. We choose the case in which the investment rate in each sector may be written as a function of the sector's "Tobin's $q^{\prime \prime}$ (the real price of equity in the sector). Households behave according to a life-cycle consumption model. Finally, domestic and foreign capital markets are fully integrated, so that home assets must earn the world rate of return. The entire model is solved as a perfect foresight, intertemporal equilibrium, in which various policies may be analyzed without being subject to the "Lucas critique." 
While some aspects of our model are loosely calibrated to the U.K. econorn, the model is not equipped at this point to assess the role of the Dutch disease in recent U.K. performance. Thus, we do not seek to add empirical estimates to the British policy debate on this issue. For stimulating contributions to that debate; see [6] for a view which attributes a large role to the Dutch disease, and $[5]$ for an opposing view.

In the next section, the barebones of the "Dutch disease" are set forth, and some of the dynamic issues are described. In section two, the full model is detailed, and may of its properties are mentioned. Specific simulation exercises are set forth in the third section, and possible extensions of this analysis are raised in the fourth and concluding section. 
I. Introduction to the Dutch Disease.

A rise in wealth in a tradeable asset (e.g. oil) leads to a rise in demand for all normal goods, including both traded and non-traded commodities. By assumption, the demand for non-traded goods can only be satisfied domestically, while the demand for tradeables can be satisfied by increased net imports. As demand rises for both types of goods, the relative price of non-traded goods must increase to preserve home-market equilibrium. Factors will be drawn into the non-traded goods sector and away from tradeables. Some of the increased demand for non-tradeables will be satisfied by increased production, and the rest will be eliminated by the rise in the relative price of non-tradeables. The increased demand for tradeables will be met by increased imports, which more than make up for the decline in their domestic production.

Fig. 1 illustrates these effects in a simple short-run static framework, in which capital is fixed within the sectors and is immobile across national boundaries, and in which capital accumulation is ignored. We suppose there are three sectors: energy (denoted by E), non-traded goods, N, and tradeables other than energy, T. For illustrative purposes, relaxed later, we can assume that all of the domestic energy is exported. Budget balance requires (in the absence of savings, investment, and internation capital flows):

$$
P_{T} Q_{T}+P_{N} Q_{N}+P_{E} Q_{E}=P_{T} C_{T}+P_{N} C_{N}
$$

where $C$ denotes consumption and $Q$ denotes domestic production. Market clearing in the non-traded goods market requires $Q_{N}=C_{N}$. We will denote the relative price on $N$ in terms of $\mathrm{T}$ as $\pi_{\mathrm{N}}\left(=\mathrm{P}_{\mathrm{N}} / \mathrm{P}_{\mathrm{T}}\right)$, and the relative price of $\mathrm{E}$ as $\pi_{\mathrm{E}}(=$ $\left.\mathrm{P}_{\mathrm{E}} / \mathrm{P}_{\mathrm{T}}\right)$. 
In an economy without oil $\left(Q_{E}=0\right)$, equilibrium would be at point $A$. A discovery of oil in this simple model would shift the consumption possibility frontier vertically in the amount $P_{E Q E}$. Non-traded good production rises, from $Q_{N} A$ to $Q_{N} B$, and the relative price of non-traded goods, $\pi_{N}$, rises (the slope at the point of tangency becomes steeper). Production of tradeables falls absolutely (from $Q_{T} A$ to $Q_{T} B$ ), while net imports of non-oil tradeables rise from zero to $C_{T} B-Q_{T} B$

In general, such a static analysis is inadequate, since the shift from $A$ to $B$ will cause profitability on capital in the two sectors to diverge and to differ from the rate of return given on world capital markets. In the long run, these rates of return must equalize, so that a "long-run" analysis might proceed as in Fig. 2. Now, we assume that physical capital flows freely between sectors and from abroad so that the marginal product of capital is always equal to $\mathrm{r}^{*}$, which is fixed on the world market. By the famous results of the Heckschen-OhlinSamuelson model, fixing $r^{*}$ also fixes the relative price of non-traded goods to traded goods, $\pi_{N}$, and forces the economy to produce on a Rybczynski line (depicted RR), along which capital in both sectors earns the marginal product $r^{*}$. In Fig.2, the RR line is drawn according to the assumption that the nontradeable sector is capital intensive. The line $\mathrm{C}\left(\pi_{\mathrm{N}}\right)$ in Fig.2 is a consumption-expansion path showing the consumption levels of $\mathrm{C}_{\mathrm{S}}$ and $\mathrm{C}_{\mathrm{T}}$ for various income levels, at the fixed relative price $\pi_{N}$. 


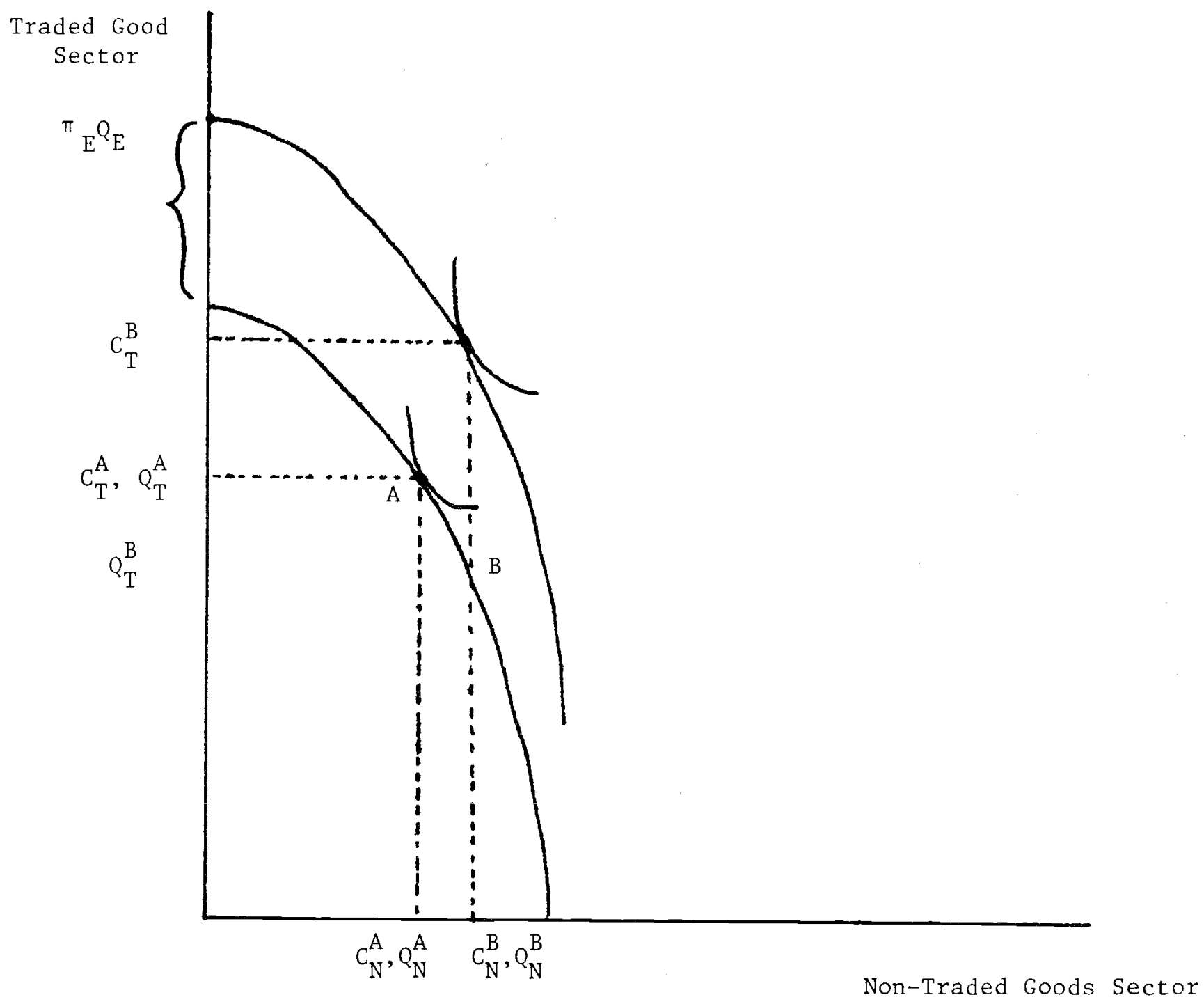

Figure 1. The Short-Run Effects of an Oil Discovery 
An economy without oil starts at equilibrium at point A. National income in tradeable units is given by the distance $O B$. An oil discovery, owned by domestic residents, raises $G D P$ by the amount $P_{E Q E}$, which is given by $B D$ in the figure. Consumption shifts to point $F$, at the intersection of $C\left(\pi_{N}\right)$ and the new national budget line.1/ By the assumption of perfect world capital mobility, the relative price $T_{N}$ remains unchanged, unlike in the short-run model above. Since the new domestic consumption of non-tradeables $C_{N}$ must be satisfied by domestic production of non-tradeables, production must lie on the RR line directly below the point $F$, at $G$ in Fig. 2. At this point, capital and labor inputs have increased absolutely in the $\mathrm{N}$-sector and have decreased absolutely in the T-sector. The basic result of the "Dutch disease" analysis is again confirmed: the (non-oil) tradeable sector is compressed by the discovery of oil. But here, international capital mobility proceeds to the point where the relative price increase of non-traded goods is completely eliminated. Also, once again, net imports of the tradeable good rise sharply.

Figures 1 and 2 provide two faces of the adjustment process, but unfortunatley we cannot simply concatenate these two figures to get a truly dynamic analysis. In general, the impact effect of the oil discovery will be a shift in investment demands in the two sectors, which will disturb the equilibrium at point $B$ in Fig. 1. More importantly, the economy will run current account imbalances as the adjustment proceeds, so that by the time that the long-run of Fig. 2 is achieved, national income will have to be adjusted to take into account the economy's net foreign investment position. For example, national income may exceed the level $O D$ (say $O D^{\prime}$ ) if the economy runs surpluses along the adjustment path, so that domestic production may occur at $H$ instead of $G$. 
Traded Good
Sector

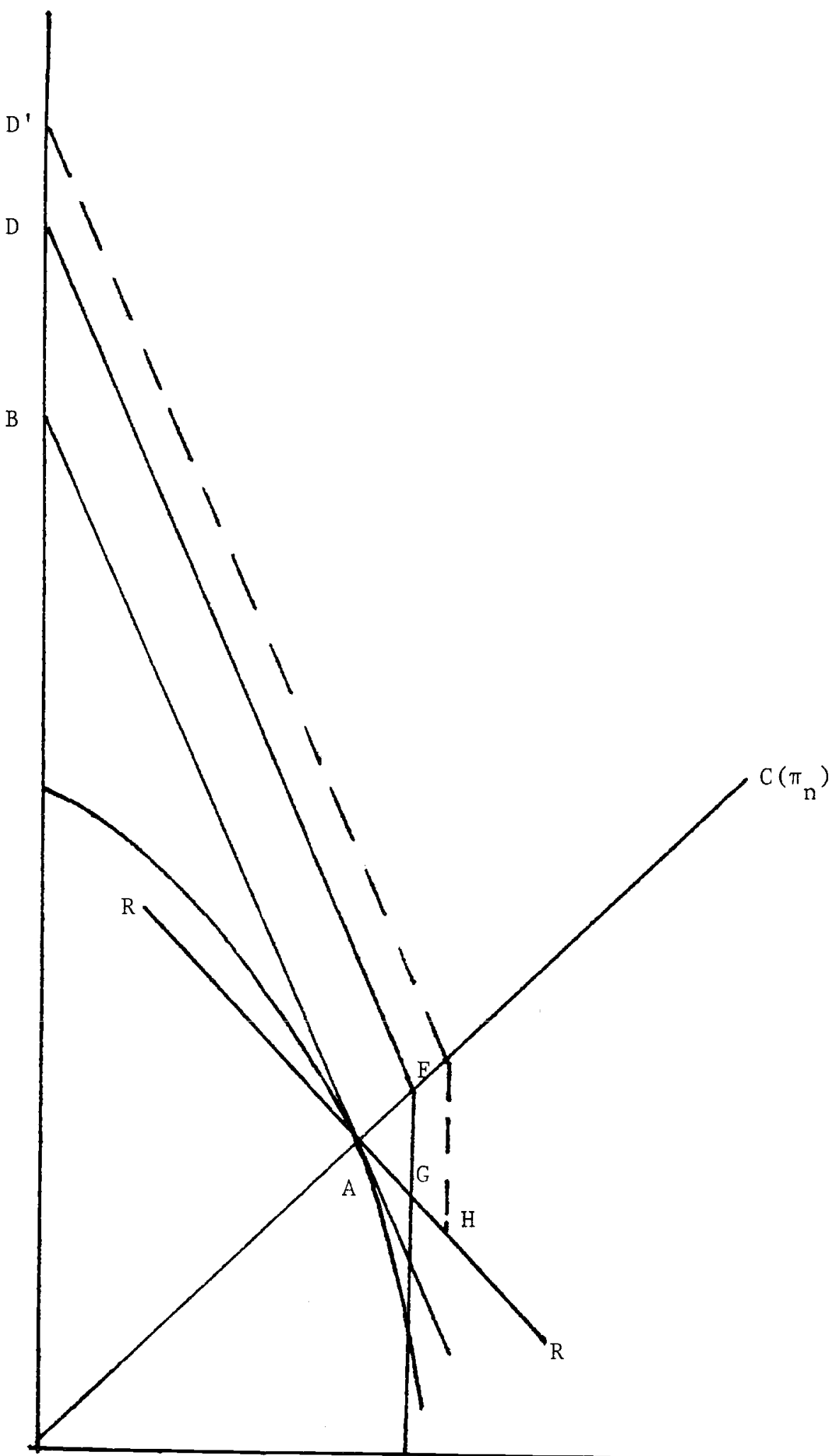

Non-Traded Goods Sector

Figure 2. Long-Run Model of Oil Discovery 
One strong motive for current account surpluses will arise if agents in the economy recognize that the oil is a depleting resource, so that current national income exceeds levels that can be expected in the future. Households may then save, and accumulate foreign assets, in order to maintain consumption levels after the oil is depleted. This is a topic to which we return.

The short-run and long-run effects on th of an oil discovery can also be seen by using sectoral factor-price frontiers (see [1] for details). In Figure 3, we draw each sector's FPF in T-good units. $w_{\mathrm{m}}\left(=\mathrm{w} / \mathrm{P}_{\mathrm{T}}\right)$ and $\mathrm{r}_{\mathrm{T}}\left(=\mathrm{r} / \mathrm{P}_{\mathrm{T}}\right)$ represents the marginal products of labor and capital in terms of good $T$. Then, the FPF in $T$ can be represented as $\Phi_{T}\left(w_{T}, r_{T}\right)=0$ and in $N$ as $w_{N}\left(w_{T} / \pi_{N}, r_{T} / T_{N}\right)=0$. The The curve 0 in Figure 3 represents the particular FPF for the initial price $\pi_{N}$. It is drawn here under the assumption that $\mathrm{N}$ is more capital intensive than $\mathrm{T}$ goods (remember that the slope of the FPF at any point measures the sector's capital-labor ratio). An increase in the relative price $\pi_{N}$ (a real appreciation) will shift this curve homothetically outwards while a decrease in $\pi_{\mathbb{N}}$ (a real depreciation) will shift it inwards.

Consider the wealth increase due to an oil discovery, as discussed above. Once again, assume that international capital mobility fixes the rate of return to capital at $r_{T}=r^{*}$ in the long-run. For both sectors to have the same wage and for $r_{T}=r^{*}$, the FPF for each sector must pass through $A$. Since the position of the FPF for $N$ moves only according to shifts in $\pi_{N}$, the longrun value of $\pi_{N}^{0}$ must be fixed at $\pi_{N}^{0}$, and must be invariant to the wealth change. In the short-run, though, 0 will jump (assuming that there are rising costs to rapidly reallocating capital among sectors), shifting the FPF 


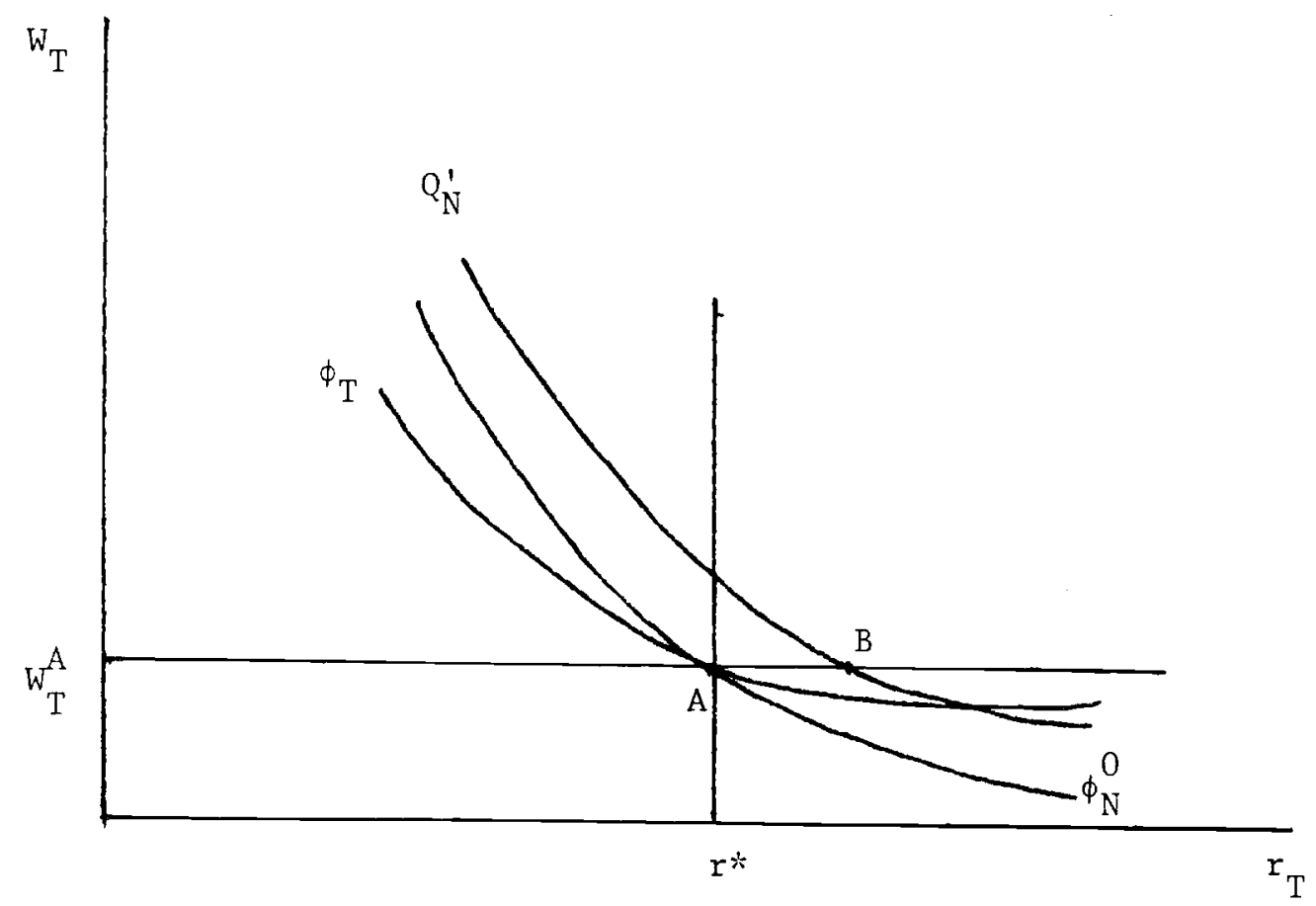

Figure 3. Factor-Price-Frontier Analysis of 0il Discovery

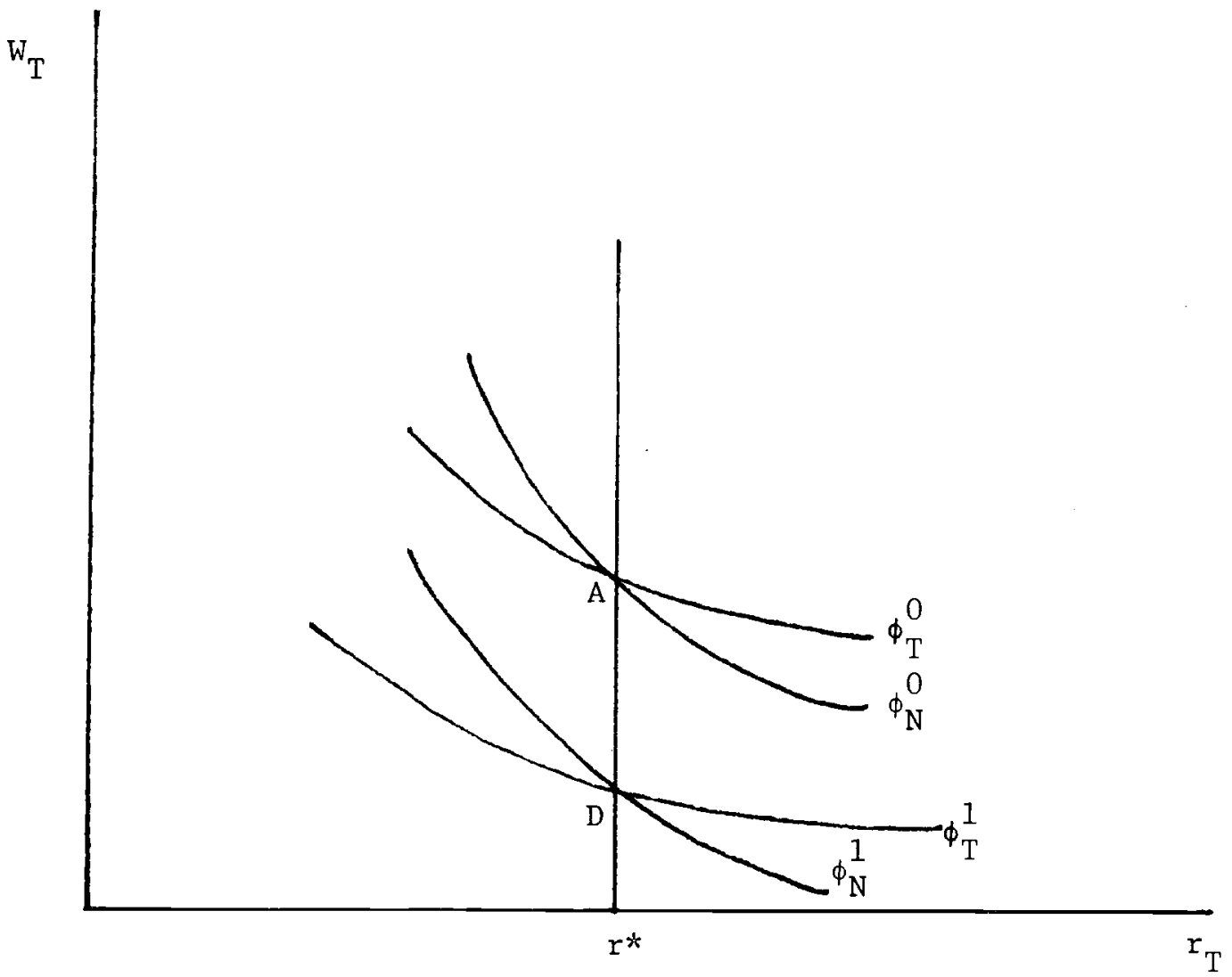

Figure 4. Factor-Price-Frontier Analysis of Rise in $\pi_{E}$ 
for the $N$ sector from $\phi_{N}$ to $\phi_{\mathbb{N}}$. At the initial product wage $w_{T}$, the profit rate in non-tradeables rises from A to $B^{\prime}$. Alternately, we may say that at the rate of interest $\mathrm{r}^{*}$, a higher wage can momentarily be maintained in the $N$ sector. Assuming that labor but not capital is shifted in the short run, labor starts moving into the $\mathbb{N}$ sector and out of tradeable goods, while the profit rate differential makes for a rise in investment in the $N$ sector and decumulation in $T$. The relative price $T_{N}$ starts falling back gradually with the FPF $\phi_{N}$ shifting back. The process comes to a halt eventually as $\pi_{N}$ returns to $\pi_{N}^{0}$ with capital labor ratios back to their initial levels. Both labor and capital inputs in $N$ have expanded and the corresponding inputs in $\mathrm{T}$ have contracted proportionately, as described earlier.

The same apparatus can be applied to study the role of $\mathrm{E}$ as an intermediate input, especially useful for the case in which th rises (as studied below). Since the $T$ sector tends empirically to be more E-intensive than the $N$ sector, we proceed under the useful stylization that $E$ is used only in $T$. The FPF in $\mathrm{T}$ becomes $\Phi_{\mathrm{T}}\left(w_{T}, r_{T}, \pi_{\mathrm{E}}\right)=0$, while the FPF in $N$ remains as before. Consider in Figure 4 the long-run effects of a rise in $\pi_{E}$ that leaves $r^{*}$ unchanged. The FPF in the $T$ sector must shift inward, with the new long-run w given along the vertical line $\mathrm{r}_{\mathrm{T}}=\mathrm{r}^{*}$ (at $\mathrm{D}$ ). The FPF for $\mathrm{N}$ must also intersect at point $\mathrm{D}$, which can only come about through a real depreciation of $\pi_{\mathrm{N}}$. The schedule shifts to $\phi_{N}^{1}$, as shown. We can also deduce that the long-run capital-labor ratio in $N$ must fall (since the tangent at $D$ has lower slope than the tangent at $A$ ).

Now we turn to the fully dynamic model which allows us to find multi-period equilibria in an econorny with far-sighted agents. 


\section{The Simulation Model}

The complete simulation model is set forth in Table 1. It is very similar in structure to the model in [8], and detailed justifications of the behavioral relations may be found in that earlier paper. We will briefly outline the structure here, proceeding through the functional blocks of the model. The equation numbers that follow refer to Table 1 . A list of variables is provided at the end of the table. All variables are written in intensive form, per unit of the full-employment labor force, which grows at rate $n$.

\section{(a) Production technology}

The economy is divided into three sectors, including two final goods ( $N$ and T) and energy (E). The final-good sectors produce according to two-level CES production functions, which combine value added with intermediate inputs. The intermediate inputs themselves involve a bundle of commodities, including energy, other imported raw materials $R$, and the output of the other final-good sector. Thus, there is a complete input-output structure for the economy. The production functions for the two final goods may be represented as:

(1.1) $\quad Q_{\mathrm{T}}=\mathrm{F}^{\mathrm{T}}\left[\mathrm{V}_{\mathrm{T}}\left(\mathrm{K}_{\mathrm{T}}, \mathrm{L}_{\mathrm{T}}\right), \mathrm{M}_{\mathrm{T}}\left(\mathrm{N}_{\mathrm{T}}, \mathrm{E}_{\mathrm{T}}, \mathrm{R}_{\mathrm{T}}\right)\right]$

$(1.2) \quad Q_{N}=F^{N}\left[V_{N}\left(K_{N}, L_{N}\right), M_{N}\left(T_{N}, E_{N}, R_{N}\right)\right]$

The $V$ and $M$ functions are each CES, with substitution elasticities $9 i$ and $\sigma_{2 i}$ respectively $(i=N, T)$.

The energy sector is assumed to use foreign inputs only, so that it does not generate any derived demands for labor or final outputs of the other two 
Table 1. The Simulation Model

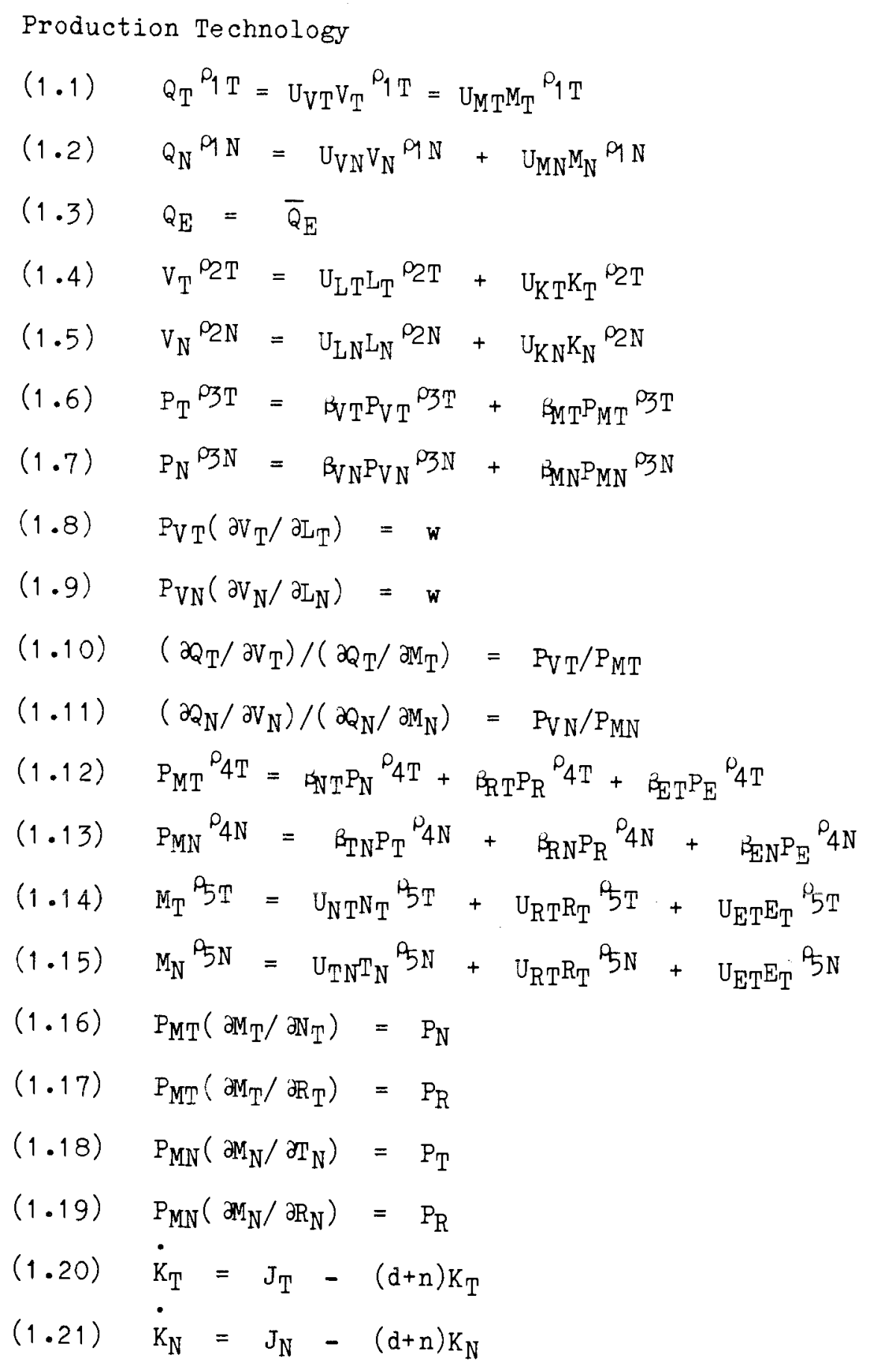


Table 1 continued

$$
\begin{array}{ll}
(1.22) & J_{T}=K_{T} \cdot\left[q_{T}-P_{J T}+P_{T} \phi(n+d) / 2\right] /(n+d) \\
(1.23) & J_{N}=K_{N} \cdot\left[q_{N}-P_{J N}+P_{N} \phi(n+d) / 2\right] /(n+d) \\
(1.24) & I_{T}=J_{T} \cdot P_{J T} \cdot\left[1+\phi / 2 \cdot\left(J_{T} / K_{T}-d-n\right)\right] \\
(1.25) & I_{N}=J_{N} \cdot P_{J N} \cdot\left[1+\phi / 2 \cdot\left(J_{N} / K_{N}-d-n\right)\right] \\
(1.26) & P_{J T}=a_{1 T} P_{T}+a_{2 T} P_{N}+a_{3 T} P_{F}+a_{4 T} P_{E} \\
(1.27) & P_{J N}=a_{1 N} P_{T}+a_{2 N} P_{N}+a_{3 N} P_{F}+a_{4 N} P_{E}
\end{array}
$$

Household Sector

$$
\begin{aligned}
& \text { (1.28) } W=H+F \\
& \text { (1.29) } F=q_{T} K_{T}+q_{N} K_{N}+w^{E}+Z \\
& \text { (1.30) } A=r(\delta-n) W+(1-r)(w L+T r) \\
& (1.31) \quad\left(\partial C / \partial C_{T}\right) /\left(\partial C / \partial C_{N}\right)=P_{T} / P_{N} \\
& (1.32)\left(\partial C / \partial C_{F}\right) /\left(\partial C / \partial C_{N}\right)=P_{F} / P_{N} \\
& \text { (1.33) }\left(\partial C / \partial C_{E}\right) /\left(\partial C / \partial C_{N}\right)=P_{E} / P_{N}
\end{aligned}
$$

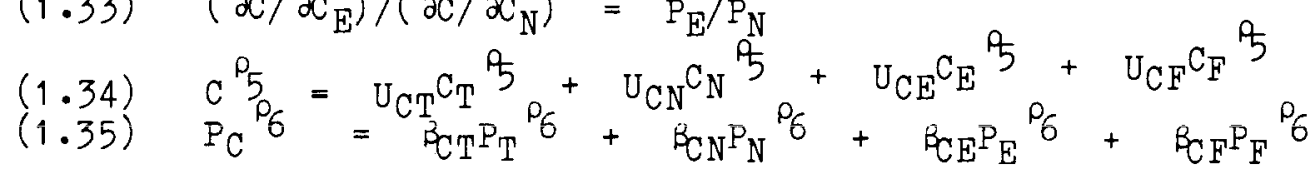

$$
\begin{aligned}
& \text { (1.36) } \mathrm{A}=\mathrm{P}_{\mathrm{T}} \mathrm{C}_{\mathrm{T}}+\mathrm{P}_{\mathrm{N}} \mathrm{C}_{\mathrm{N}}+\mathrm{P}_{\mathrm{E}} \mathrm{C}_{\mathrm{E}}+\mathrm{P}_{\mathrm{F}} \mathrm{C}_{\mathrm{F}} \\
& \text { (1.37) WE }=\int_{0}^{\infty} P_{E^{Q} E}\left(1-\tau_{e}\right) e^{-r^{*} t} d t
\end{aligned}
$$


Market Equilbrium Conditions

$$
\begin{aligned}
& \text { (1.38) } \quad \dot{q}_{\mathrm{T}} / \mathrm{q}_{\mathrm{T}}=\mathrm{r}^{*}-D i \mathrm{v}_{\mathrm{T}} / \mathrm{q}_{\mathrm{T}} \mathrm{K}_{\mathrm{T}} \\
& \text { (1.39) } \quad \dot{q}_{N} / q_{N}=r^{*}-D i v_{N} / q_{N} K_{N} \\
& \text { (1.40) } \dot{H} / \mathrm{H}=\mathrm{r}^{*}-(\mathrm{w}+\mathrm{Tr}) / \mathrm{H}-\mathrm{n} \\
& \text { (1.41) } \lim _{t \rightarrow \infty} e^{-r^{*}} t_{q_{T}}=0 \\
& \text { (1.42) } \lim _{t \rightarrow \infty} e^{-r^{*}} t_{q N}=0 \\
& \text { (1.43) } \lim _{t \rightarrow \infty} e^{-r^{*}} t_{H}=0 \\
& \text { (1.44) } Q_{\mathrm{T}}=\mathrm{C}_{\mathrm{T}}+\left[\mathrm{a}_{1 \mathrm{~T}} \mathrm{~J}_{\mathrm{T}}+\mathrm{a}_{1 \mathrm{~N}} \mathrm{~J}_{\mathrm{N}}+\left(\mathrm{I}_{\mathrm{T}} / \mathrm{P}_{\mathrm{JT}}-\mathrm{J}_{\mathrm{T}}\right)\right]+\mathrm{X}_{\mathrm{T}}+\mathrm{T}_{\mathrm{N}} \\
& \text { (1.45) } Q_{N}=C_{N}+\left[a_{2 T} J_{T}+a_{2 N} J_{N}+\left(I_{N} / P_{J N}-J_{N}\right)\right]+N_{T} \\
& \text { (1.46) } \operatorname{Div}_{\mathrm{T}}=\mathrm{PVTV}_{\mathrm{T}}-\mathrm{wL}_{\mathrm{T}}+\mathrm{q}_{\mathrm{T}}\left[\mathrm{J}_{\mathrm{T}}-(\mathrm{d}+\mathrm{n}) \mathrm{K}_{\mathrm{T}}\right]-\mathrm{I}_{\mathrm{T}} \\
& \text { (1.47) } \operatorname{Div}_{N}=P_{V_{N} V_{N}}-w_{N}+q_{N}\left[J_{N}-(d+n) K_{N}\right]-I_{N} \\
& (1.48 \mathrm{a}) \mathrm{L}_{\mathrm{T}}+\mathrm{L}_{\mathrm{N}}=\overline{\mathrm{L}} \\
& (1.48 \mathrm{~b}) \dot{\mathrm{W} / \mathrm{W}}=\dot{\mathrm{P}}_{\mathrm{C}} / \mathrm{P}_{\mathrm{C}}+\rho \log \left[\left(\mathrm{L}_{\mathrm{T}}+\mathrm{L}_{\mathrm{N}}\right) / \mathrm{L}\right]
\end{aligned}
$$

Balance of Payments

$(1.49) \quad \dot{Z}=\left(P_{V T} V_{T}+P_{V N} V_{N}+P_{E Q E}+r_{Z}^{*}\right)-\left(A+I_{T}+I_{N}\right)-n Z$

$(1.50) \quad X_{T}=\zeta\left(P_{T} / P_{F}\right)^{-P_{S}} \cdot W^{*}$

Fiscal Policy

$$
\begin{aligned}
& (1.51 \mathrm{a}) \quad \operatorname{Tr}=\tau_{\mathrm{E}} \cdot \mathrm{P}_{\mathrm{E}} \mathrm{QE}_{\mathrm{E}} \\
& (1.51 \mathrm{~b}) \quad \operatorname{Tr}=\mathrm{r}^{*} \cdot \mathrm{W}^{\mathrm{E}} \cdot \tau \mathrm{\tau e} /(1-\tau e)
\end{aligned}
$$


Table 1 continued

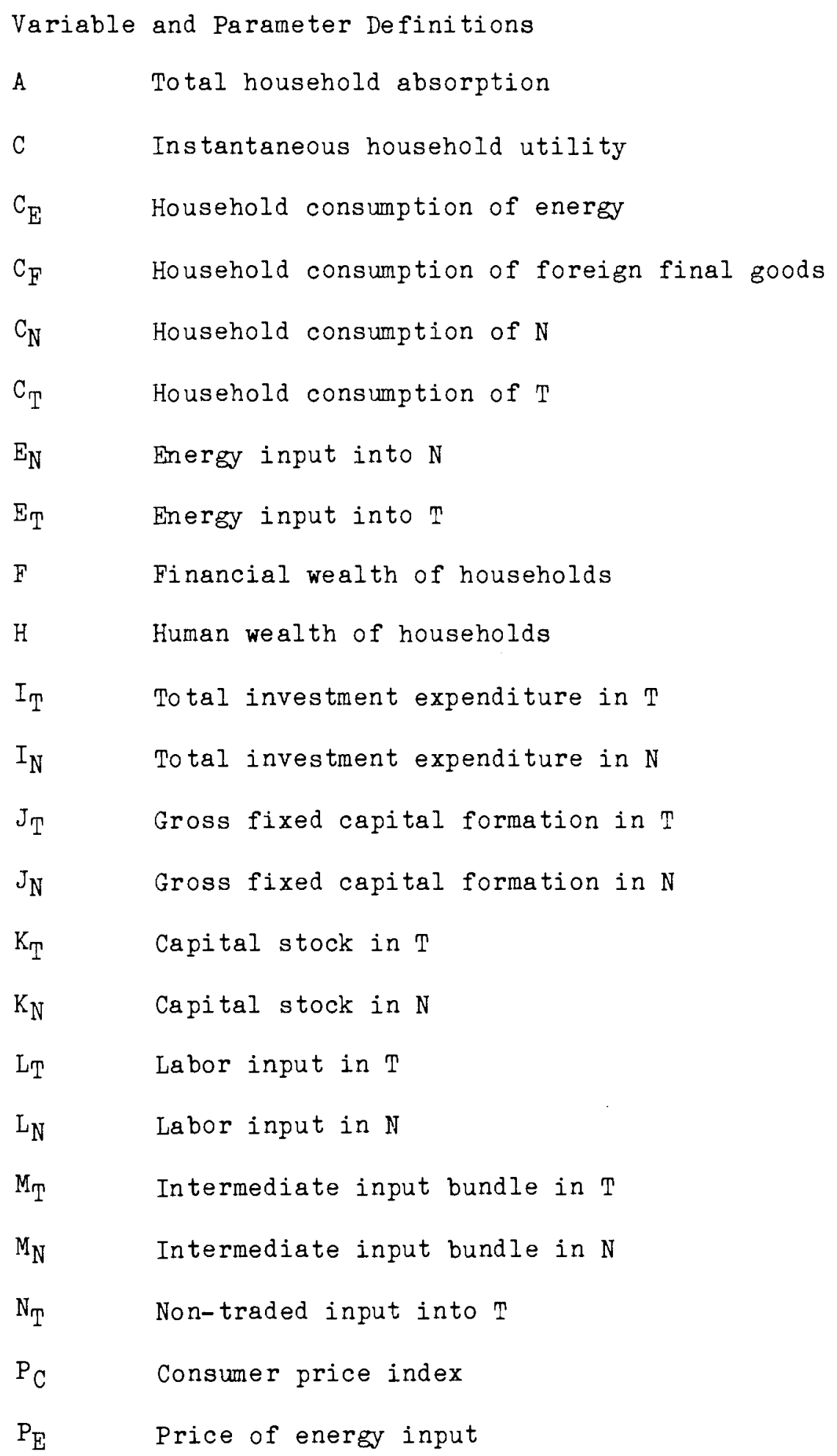




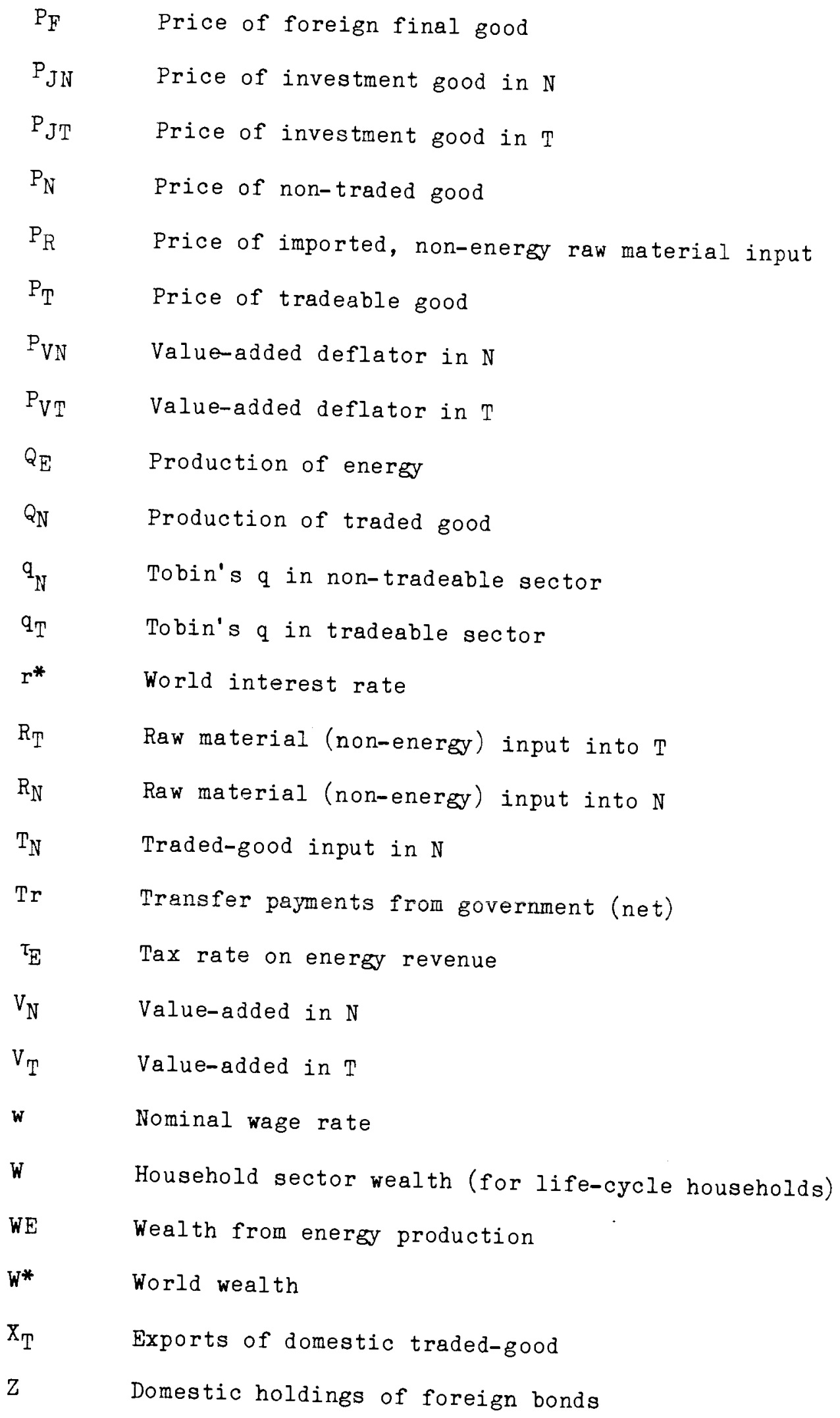


Table 1 continued

Other parameters

d Rate of depreciation

n Rate of population growth

$\delta \quad$ Rate of time preference for life-cycle savers

$\Phi \quad$ Cost-of-adjustment parameter in investment functions

36 Proportion of life-cycle households in total

Notes to Table 1

1. At any moment, $K_{T}, K_{N}$, and $z$ are predetermined. $W^{*}, r^{*}, Q_{E}, P_{F}, P_{R}, P_{E}$, and the parameter values of the model are exogenous. Thus, the $\pi$ equations determine: $Q_{T}, V_{T}, M_{T}, Q_{N}, V_{N}, M_{N}, Q_{E}, L_{T}, L_{N}, P_{T}, P_{V T}, P_{V N}, P_{N}, P_{V N}, P_{M N}$, $N_{T}, R_{T}, E_{T}, T_{N}, R_{N}, E_{N}, J_{T}, J_{N}, I_{T}, I_{N}, k_{T}, k_{N}, q_{T}, q_{N}, P_{J T}, P J N, W, H, F$, $W^{E}, A, C_{T}, C_{N}, C_{E}, C_{F}, C, P_{C}, \dot{q}_{T}, \dot{q}_{N}, H, D i v_{T}$, Di $v_{N}, Z, X_{T}, T r$, and $w$ or $\dot{w}$ (depending on $(1.48 a)$ or $(1.48 b))$. In the case of $(1.48 b), w_{c}\left(w / P_{c}\right)$ is predetermined. Note that current the values of $H, q_{T}, Q_{N}$ are determined implicitly by the transversality conditions (1.41), (1.42), and (1.43).

2. Equation pairs $(1.4),(1.6) ;(1.5),(1.7) ;(1.12),(1.14) ;(1.13),(1.15)$; $(1.34),(1.35)$ are iinked by duality relationships, as spelled out in our study [2]. The parameters in these equations are therefore subject to cross-equation restrictions. 
sectors. Indeed, in this model, the issue of time pattern of oil production and "optimal depletion policy" is ignored, as the cash flow from energy production is treated as exogenous.

The production functions (1.1) and (1.2) imply dual relationships linking the prices of the final outputs with the prices of the various inputs. As we described in [2], these relationships are also of the CES type, since the CES function is "self-dual". Thus, we have:

(1.6) $\quad \mathrm{P}_{\mathrm{T}}=\mathrm{Q}^{\mathrm{T}}\left[\mathrm{P}_{\mathrm{VT}}, \mathrm{P}_{\mathrm{MT}}\left(\mathrm{P}_{\mathrm{N}}, \mathrm{P}_{\mathrm{E}}, \mathrm{P}_{\mathrm{R}}\right)\right]$

(1.7) $\quad P_{N}=Q^{N}\left[P_{V N}, P_{M N}\left(P_{T}, P_{E}, P R\right)\right]$

Note that these equations implicitly define the true value-added deflators $P_{V T}$ and $P_{V N}$ in terms of the other prices.

At any moment, the capital stocks in the final-good sectors are predetermined. Output supply functions conditional on $K_{T}$ and $K_{N}$ may then be derived, as was shown in detail in our essay [2] in this volume. Specifically, we impose the first-order conditions that $\partial V_{i} / \partial L_{i}=W / P_{V_{i}}, \partial Q_{i} / \partial V_{i}=P_{V_{i}} / P_{i}$, $\partial Q_{i} / \partial M_{i}=P_{M_{i}} / P_{i}, \quad(i=T, N)$, etc., as in equations (1.8) to $(1.11)$ in Table 1.

The optimal investment policy for the firm makes the rate of gross physical capital formation an increasing furnction of the sectoral Tobin's q (see [2] for an extended discussion). For each sector, a unit of physical capital is a composite good, involving a fixed proportion of four commodities, so that $P_{I}$ is a weighted average of $\mathrm{P}_{\mathrm{N}}, \mathrm{P}_{\mathrm{T}}, \mathrm{P}_{\mathrm{E}}$, and $\mathrm{P}_{\mathrm{R}}$. The investment equations are shown in Table 1 as $(1.22)$ and $(1.23)$. 
(b) Household Sector

Households supply labor, hold asset portfolios, and make consumption choices among traded, non-traded, energy, and imported final goods. We assume that a portion $\Omega$ of all households are perfect life-cycle savers, optimizing consumption expenditure over an infinite horizon. The remaining proportion $(1-\Omega)$ of households are myopic or credit-constrained, and these households merely consume their labor income, without accumulating or holding financial assets. This division in households is made in recognition of the empirical evidence on consumption expenditure that shows current consumption to be more closely tied to current income than is predicted by a pure life-cycle model.

For a given class of intertemporal utility functions, life-cycle households choose total consumption expenditure $\mathrm{p}_{C} \mathrm{C}$ as a fixed fraction $\delta$ of contemporaneous wealth: $\mathrm{p}_{\mathrm{C}} \mathrm{C}=\mathrm{W}$. A rigorous justification for this equation may be found in [8]. Non-life cycle households simple spend $(w+T r) L$, where $\operatorname{Tr}$ are net per capita transfers from the government. Total private absorption is the sum of spending of these two groups:

$$
A=\Omega \cdot d W+(1-\Omega) \cdot(w+T r) \cdot L
$$

Once total spending is chosen, households divide expenditures among the variety of available goods, including $N, T, E$, and $F$ (the foreign final good). Thus, $A=P_{E} C_{E}+P_{T} C_{T}+P_{N} C_{N}+P_{F} C_{F}$, with the consumption levels selected to maximize an instaneous CES utility function. The consumption equations are given in the model as (1.31) thru (1.33). 
Next, consider wealth (W) held by the life-cycle households. This is comprised of human wealth and financial wealth. Human wealth is the discounted value of future labor income (inclusive of net transfers from the government) as implied by (1.40). Financial wealth is the sum of equity and bond holdings and oil wealth, where the latter is the post-tax discounted value of the future stream of oil revenues. (See (1.29) and (1.37) in Table 1.)

\section{(c) Market equilibrium conditions}

There are three types of market equilibrium conditions: for assets, commodities and factor inputs. For assets, we assume that the foreign bond, and domestic equity claims to capital in the $\mathrm{N}$ and $\mathrm{T}$ sectors are all perfect substitutes, so that the ex ante expected yields must be identical. The foreign bond has a fixed instantaneous yield $\mathrm{r}^{*}$. The yield on domestic equity is the sum of the dividend yield $\left(D_{i} v_{i} / q_{i} K_{i}\right)$ and capital gains $\left(\dot{q}_{i} / q_{i}\right)$, so that (1.38) $\quad r^{*}=\left(D_{i} v_{i} / q_{i} K_{i}\right)+\left(\dot{q_{i} / q_{i}}\right) \quad i=T, N$

The expression for dividends is given in (1.46), and is based on the assumption of all-equity firms with no retained earnings (see [8] for a more complete discussion).

There are market equilibrium conditions for the final goods sectors, that require:

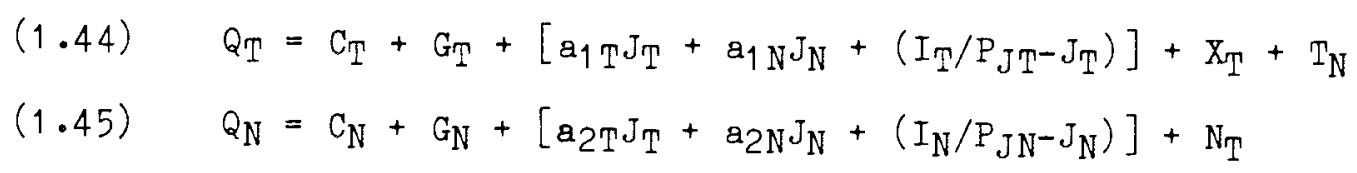


The bracketed expressions represent the inputs of each sector into investment demand. Note that one element of final demand for the tradeable commodity is export demand $\mathrm{X}_{\mathrm{T}}$ (which is of course not present in the non-traded sector). $\mathrm{X}_{\mathrm{T}}$ is written as a function of exogenous foreign wealth $\mathrm{w}^{*}$, and the relative price of the foreign final good:

$(1.50) \quad X_{T}=\zeta\left(P_{T} / P_{F}\right)^{-} P_{W_{W}^{*}}$

We do not need market clearing equations for energy, raw materials, or the foreign final good, since we assume that these commodities are in perfectly elastic supply on the world market.

The model is solved under two alternative assumptions for the labor market, either (a) full employment, with flexible real wages; or (b) less-than-fullemployment, with sluggish real wage adjustrent as a function of the rate of unemployment. Under assumption (a)

$(1.48 a) \quad \bar{L}=I_{T}+L_{N}$

and under (b)

$(1.48 b) \quad \dot{W} / W-\dot{P}_{C} / P_{C}=\rho\left[\bar{L}-\left(L_{T}+L_{N}\right)\right] / \bar{L}$

Finally, there are the balance of payment accounting relationships, according to which the accumulation of foreign bonds by domestic residents equals the current account surplus: $(\dot{z})_{t}=C A_{t}$. The current account is given as the difference of national income and national absorption, in (1.49). 
Simulation Results

The model parameters used in the simulations (Table 2) are "guesstimates" rather than econometric estimates. Mr. Louis Dicks-Mireaux of Harvard University is now engaged in a careful econometric specification of the model. Thus, the estimates here are meant to provide a plausible order of magnitude for various effects, rather than precise measures.

To choose parameters for the production block of the model, our econometric estimates in [2] for the manufacturing sector of the U.K. were used as a benchmark, alongside the 1973 input-output table of the United Kingdom. Thus, the elasticity of substitution between $V_{i}$ and $M_{i}$, and between $K_{i}$ and $I_{i}$, is conservatively set at 0.2 . The elasticity of substitution among the components of $M_{i}$ is set at 0.5 . The remaining parameters of the production function are then selected to yield the 1973 factor shares as shown in the input-output table. The procedure yielded the following production relations:

$$
\begin{aligned}
& Q_{\mathrm{T}}=\left[.43 \mathrm{~V}_{\mathrm{T}}-.25+.41 \mathrm{M}_{\mathrm{T}}-.25\right]-4 \\
& \mathrm{Q}_{\mathrm{N}}=\left[.68 \mathrm{~V}_{\mathrm{N}}-.25+.19 \mathrm{M}_{\mathrm{N}}-.25\right]-4 \\
& V_{\mathrm{T}}=\left[.72 \mathrm{I}_{\mathrm{T}}-.25+.16 \mathrm{~K}_{\mathrm{T}}-.25\right]-4 \cdot(.62) \\
& \mathrm{V}_{\mathrm{N}}=\left[.52 \mathrm{~L}_{\mathrm{N}}-.25+.26 \mathrm{~K}_{\mathrm{N}}-.25\right]-4 \cdot(.55) \\
& \mathrm{M}_{\mathrm{T}}=\left[2.5 \mathrm{~N}_{\mathrm{T}}{ }^{-1}+.09 \mathrm{E}_{\mathrm{T}}{ }^{-1}+1.65 \mathrm{R}_{\mathrm{T}}-1\right]-1 \\
& \mathrm{M}_{\mathrm{N}}=\left[.41 \mathrm{~T}_{\mathrm{N}}^{-1}+.07 \mathrm{E}_{\mathrm{N}}^{-1}+.79 \mathrm{R}_{\mathrm{N}}{ }^{-1}\right]^{-1}
\end{aligned}
$$

Three simulation exercises were undertaken to illuminate the links of North Sea oil to the rest of the U.K. economy. First, we consider alternative budgetary methods of redistributing the proceeds of oil revenue taxes to the public. 
Table 2. Key Parameter Values for Simulation

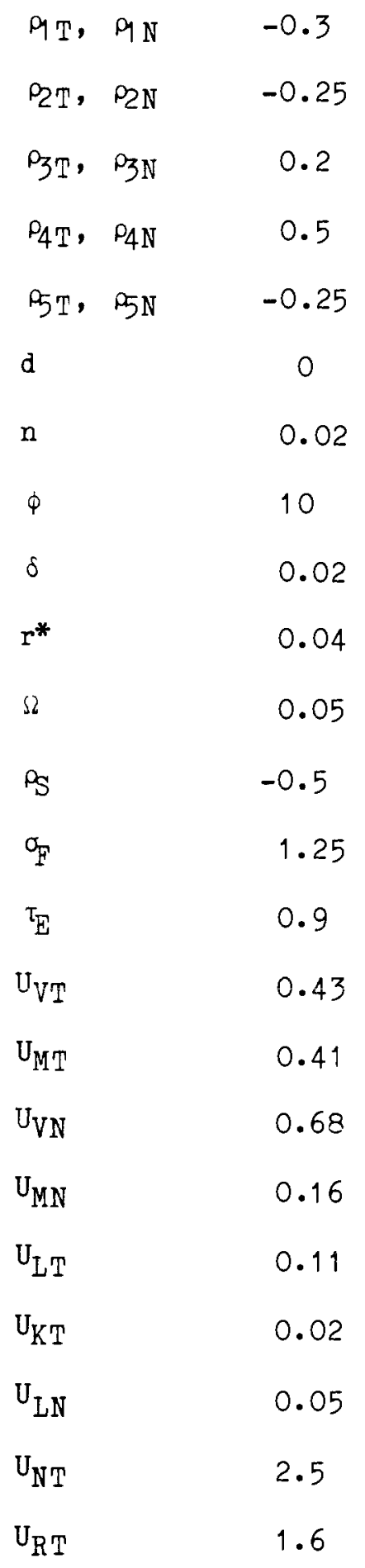


Table 2 continued

$\begin{array}{ll}U_{E T} & 0.09 \\ U_{T N} & 0.41 \\ U_{R N} & 0.07 \\ U_{E N} & 0.79 \\ a_{1 \mathrm{~T}} & 0.3 \\ a_{2 \mathrm{~T}} & 0.6 \\ a_{3 \mathrm{~T}} & 0.1 \\ a_{4 \mathrm{~T}} & 0.014 \\ a_{1 \mathrm{~N}} & 0.3 \\ a_{2 \mathrm{~N}} & 0.6 \\ a_{3 N} & 0.1 \\ a_{4 N} & 0.014 \\ \beta_{C T} & 0.333 \\ B_{C N} & 0.486 \\ \beta_{C E} & 0.059 \\ \beta_{C F} & 0.132\end{array}$

Note that the production function parameters are also shown on p. 23. 
Second, we analyze the effects of a rise in energy prices, under the contrasting assumptions of flexible and fixed real wages. Third, we study the dynamic responses to a domestic oil discovery. It is important to stress again that the simulation results provide qualitative rather than quantitative measures of the effects of the various disturbances, since the model is only loosely calibrated to the U.K. economy.

All results are stated as percentage deviations from a base case, in which the economy is on an equilibrium growth trajectory. In the base case, the economy is characterized by a declining stream of domestic energy production, very similar to that assumed by Forsyth and Kay [5]. For the first 15 years, domestic energy production exceeds energy consumption by about ten percent; energy production then falls by 50 percent for the following 15 years, and falls again by half (to 25 percent of original production) for the remaining horizon of the economy. With an assumed world real interest rate of four percent, these assumptions make the country a net energy importer in present value terms (but presumably much less of one than the U.K.'s competitors).

Simulation 1: Budget Policy and Oil Revenues

Under current projections, over 80 percent of North Sea oil earnings will be collected in taxes in the next decade. An important issue of public policy is how to manage the government budget in light of the oil revenues, both in terms of expenditure and debt policy. In this first exercise, we focus on debt management for a given trajectory of expenditure on goods and services. 
Increased revenue from oil taxes can be used to reduce public debt (or equivalently, accumulate official reserves) or to make increased transfer payments to the private sector. As is well known, this choice is irrelevant under assumptions of perfect foresight, competitive capital markets, and infinitely-lived households (i.e., households with an operative bequest motive between generations). However, for finite-lived or capital-constrained households, the budget decision has an important bearing on the intertemporal distribution of consumption expenditure, and thus on prices, output, and capital accumulation as well. As described earlier, $(1-\Omega)$ percent of the households in this model are "capital constrained", so that the budget choices will affect the growth path of the economy. In the simulations we set $\Omega$ equal to 0.5 .

As a simple illustration, consider two alternative policies. In the base case, the government simply returns current tax revenue in transfers (we label this the "current-transfer" policy); in the second case, the government pays out in each period the constant, perpetuity-equivalent of its oil revenues (we label this the "constant-transfer" policy). Since oil revenues decline over time with the diminution of production, the current transfer is initially greater, and then later less, than the perpetuity-equivalent transfer. In the constanttransfer case, the government initially runs a budget surplus to build up reserves, the income of which is then used to sustain transfers after oil production subsides.

In sum, a switch from a current to a constant transfer policy shifts consumption to a later date, and smooths the intertemporal path of consumption expenditure and presumably the intertemporal distribution of utility across generations. In terms of the equilibrium in Figure 2, production is farther out 
along the RR line in equilibrium (e.g., at point $H$ rather than G), so that there is greater non-tradeable production and less tradeable sector production than under a current-transfer regime. The analogy to Figure 2 is close but not perfect, though, since in the simulation model, $P_{N} / P_{T}\left(\pi_{N}\right)$ may change slightly in equilibrium, and the relative price of domestic tradeable to foreign tradeable final goods, $\mathrm{P}_{\mathrm{T}} / \mathrm{P}_{\mathrm{F}}$, may also vary. (The movement of $\mathrm{T}_{\mathrm{N}}$ apparently results from the fact that the real price of investment goods $P_{J N} / P_{T}$ and $\mathrm{P}_{\mathrm{JT}} / \mathrm{P}_{\mathrm{T}}$ vary in the long run.)

The specific quantitative results of the policy shift are shown in Table 3 . Under the constant-transfer policy, consumption and the terms of trade $P_{T} / P_{F}$ are reduced in the early years, as is the relative price of non-traded goods to traded goods $\mathrm{P}_{\mathrm{N}} / \mathrm{P}_{\mathrm{T}}$. Because of the terms-of-trade effect, real wages fall by 0.2 percent. Since $\mathrm{P}_{\mathrm{N}} / \mathrm{P}_{\mathrm{T}}$ falls, production in the traded goods sector is stimulated, and $\mathrm{K}_{\mathrm{T}}$ is higher in the short run, relative to the current-transfer case. Over time, the consumption expenditure in the constant-transfer policy rises relative to consumption in the base case, so that short-run effects are essentially reversed in the long-run. By sustaining consumption in the long-run, the constant-transfer policy results in higher steady-state $\mathrm{P}_{\mathrm{T}} / \mathrm{P}_{\mathrm{F}}$ and $\mathrm{P}_{\mathrm{N}} / \mathrm{P}_{\mathrm{T}}$. The higher long-run consumption level means a larger non-traded goods sector, and a reduced traded-goods sector. Thus, $\mathrm{K}_{\mathrm{N}}$ is 0.6 percent higher in equilibrium and $\mathrm{K}_{\mathrm{T}}$ is 0.3 percent lower than under the current transfer policy. 
Table 3: Effects of a Shift to a Constant-Transfer Policy

$\begin{array}{lcccc} & 1980 & 1985 & \frac{1990}{\text { Steady-State }} \\ \mathrm{K}_{\mathrm{T}} & 0.0 & 0.2 & 0.4 & -0.3 \\ \mathrm{~K}_{\mathrm{N}} & 0.0 & 0.0 & 0.2 & 0.6 \\ \mathrm{P}_{\mathrm{T}} / \mathrm{P}_{\mathrm{F}} & -0.6 & -0.5 & 0.2 & 0.3 \\ \mathrm{P}_{\mathrm{N}} / \mathrm{P}_{\mathrm{T}} & -0.6 & -0.2 & -0.2 & 0.2 \\ \mathrm{Q}_{\mathrm{T}} / \mathrm{L}_{\mathrm{T}} & -0.2 & -0.2 & -0.1 & 0.1 \\ \mathrm{Q}_{\mathrm{N}} / \mathrm{L}_{\mathrm{N}} & 0.0 & 0.0 & 0.0 & 0.1 \\ \mathrm{~W} / \mathrm{CPI} & -0.2 & -0.2 & -0.2 & 0.2\end{array}$

All variables are measured by their percentage change over base-case values, where in the base case all oil tax revenues are redistributed in the period of their collection. 
Simulation 2: A Five-Percent Increase in World Energy Prices

Next, we study a small increase in the world price of energy, first under the assumption of continuous full-employment, and then with sluggishness in real wages. We assume a constant-transfer policy for government revenues. The specific shock is aa permanent, unanticipated, one-shot rise in the world energy price of five percent in 1980. The effects are shown in Table 4. Details for a single sector's adjustment to higher $P_{E}$ may be found in our study [2].

The novel effect here is the differential behavior of the final goods sectors, which results from the higher energy-intensity of production in traded goods (again, see Bruno [1] for details). When energy prices rise, full employment requires a 0.4 percent drop in real wages, as shown in Table 5 . Substitution away from energy inputs reduces labor productivity in the tradeable sector. $Q_{N} / L_{N}$ is also reduced as labor shifts from the traded to the nontraded goods sector. Because of the shift of labor into non-tradeables, the marginal product of capital in $\mathrm{N}$ actually rises when energy prices increase and that sector's capital accumulation increases very slightly. Profitability in $\mathrm{T}$, on the other hand, is hard hit, and investment in $\mathrm{T}$ is sharply negative. In the steady state, $K_{N}$ rises by 0.1 percent while $K_{\mathrm{T}}$ falls by 0.3 percent.

With temporary real wage rigidity, as shown in Table 5, the unemployment rate jumps one percentage point upon impact of the oil shock, falling over time at a rate of about 0.2 percentage points per year. The unemployment depresses investment, but only slightly, since rational entrepreneurs know that the unemployment (and resulting low profits) are temporary. In $1985, K_{\mathrm{T}}$ and $\mathrm{K}_{\mathrm{N}}$ are 
a mere one-tenth of one percent lower than in the full employment case. Finally, note that the real wage rigidity worsens the economy's international competitiveness after the oil shock, with $\mathrm{P}_{\mathrm{T}} / \mathrm{P}_{\mathrm{F}}$ about 0.4 percent higher during 1980 than in the full-employment case.

Simulation 3: Evaluating the Effects of the North Sea Oil Sector:

The Dutch Disease

Forsyth and Kay, among others, have studied the resource allocational consequences of the North Sea oil production. The present model is well-suited to such a task, though it is not yet calibrated on the demand side. To get a feel for the major qualitative effects of the North Sea oil boom, we compare simulations of the economy with and without domestic energy production. The effects of a one-shot move from no production to self-sufficiency are illustrated in Table 6. We assume that energy production immediately, costlessly, and unexpectedly comes on line in 1980, and then follows the declining production profile outlined earlier.

The results support most qualitative points in Forsyth and Kay's astute analysis, though there are also important differences. The domestic oil wealth improves the country's terms of trade $\left(\mathrm{P}_{\mathrm{T}} / \mathrm{P}_{\mathrm{F}}\right)$ by 0.2 percent initially, and raises the relative price of home to traded goods by 1.1 percent. There is substantial shift of labor to the non-traded goods sector, and production $Q_{N}$ rises by 2.7 percent, while $Q_{T}$ falls by 1.9 percent. Average labor productivity in non-traded goods accordingly falls by -0.1 percent initially. The terms-of-trade improvement also raises real wages by 0.8 percentage points. 
Forsyth and Kay correctly indicate that the benefits of North Sea oil are in large part enjoyed through a relative expansion of the non-traded goods sector. Thus, the oil discovery prompts a boom in investment in $N$, and a squeeze in investment and profits in T. By $1985, K_{N}$ rises by 1.2 percent and $K_{T}$ falls by 0.7 percent. Importantly, the continued expansion of the non-traded goods sector and decline of the traded goods sector substantially reverses the relative price increase $\mathrm{P}_{N} / \mathrm{P}_{\mathrm{T}}$. In the long run, $\mathrm{P}_{\mathrm{N}} / \mathrm{P}_{\mathrm{T}}$ falls back to 0.3 percent above its initial value.

An important point not stressed by Forsyth and Kay is that optimizing rational households (and government) will not consume all current oil revenues, but will rather save in anticipation of the future decline in energy production. Thus, much of the current energy revenues will show up in current account surpluses. To the extent that the revenues are saved in the short run, the sectoral reallocation of production is postponed for the future. And to the extent that the current revenues overstate the "perpetuity equivalent" of oil earnings (i.e., to the extent that current production exceeds "permanent production"), a focus on current production levels overstates the resource allocational consequences of the oil sector. 
Table 4. Energy Price Increase (5 Percent): Flexible Wages

$\begin{array}{lcccc} & 1980 & 1985 & \underline{1990} & \text { Steady-State } \\ \mathrm{K}_{\mathrm{T}} & 0.0 & -0.2 & -0.3 & -0.5 \\ \mathrm{~K}_{\mathrm{N}} & 0.0 & 0.0 & 0.1 & 0.1 \\ \mathrm{P}_{\mathrm{T}} / \mathrm{P}_{\mathrm{F}} & 0.3 & 0.3 & 0.3 & 0.3 \\ \mathrm{P}_{\mathrm{N}} / \mathrm{P}_{\mathrm{T}} & 0.0 & 0.0 & -0.1 & -0.1 \\ \mathrm{Q}_{\mathrm{T}} / \mathrm{L}_{\mathrm{T}} & -0.2 & -0.2 & -0.2 & -0.2 \\ \mathrm{Q}_{\mathrm{N}} / \mathrm{L}_{\mathrm{N}} & -0.2 & -0.2 & -0.2 & -0.2 \\ \mathrm{~W} / \mathrm{CPI} & -0.4 & -0.4 & -0.4 & 0.5\end{array}$

All variables are measured by their percentage change over base-case values. For this set of simulations, the government pursues a constant-transfer policy. 
Table 5. Energy Price Increase (5 percent): Sluggish Real Wages

$\begin{array}{lcccc} & 1980 & 1985 & \underline{1990} & \text { Steady-State } \\ \mathrm{K}_{\mathrm{T}} & 0.0 & -0.3 & -0.4 & -0.5 \\ \mathrm{~K}_{\mathrm{N}} & 0.0 & -0.1 & -0.0 & 0.1 \\ \mathrm{P}_{\mathrm{T}} / \mathrm{P}_{\mathrm{F}} & 0.7 & 0.4 & 0.3 & 0.3 \\ \mathrm{P}_{\mathrm{N}} / \mathrm{P}_{\mathrm{T}} & 0.0 & 0.0 & 0.0 & -0.1 \\ \mathrm{Q}_{\mathrm{T}} / \mathrm{L}_{\mathrm{T}} & 0.1 & -0.1 & -0.2 & -0.2 \\ \mathrm{Q}_{\mathrm{N}} / \mathrm{L}_{\mathrm{N}} & 0.1 & 0.2 & -0.2 & -0.2 \\ \begin{array}{l}\mathrm{W} / \mathrm{CPI} \\ \begin{array}{l}\text { Unerployment } \\ \text { Rate (percent) }\end{array}\end{array} & 1.0 & 0.2 & 0.0 & 0.0\end{array}$

All variables except rate of unemployment are measured by their percentage change over base-case values. For this set of simulations, the government pursues a constanttransfer policy. 
Table 6. Energy Sector Windfall: Estimated Effects

$\begin{array}{lcccc} & 1980 & \frac{1985}{1990} & \text { Steady-State } \\ \mathrm{K}_{\mathrm{T}} & 0.0 & -0.7 & -1.1 & -1.3 \\ \mathrm{~K}_{\mathrm{N}} & 0.0 & 1.2 & 2.0 & -3.2 \\ \mathrm{P}_{\mathrm{T}} / \mathrm{P}_{\mathrm{F}} & 2.0 & 2.0 & 2.1 & 1.8 \\ \mathrm{P}_{\mathrm{N}} / \mathrm{P}_{\mathrm{T}} & 1.1 & 0.8 & 0.6 & 0.3 \\ \mathrm{Q}_{\mathrm{T}} / \mathrm{L}_{\mathrm{T}} & 0.8 & 0.8 & 0.8 & 0.7 \\ \mathrm{Q}_{\mathrm{N}} / \mathrm{L}_{\mathrm{N}} & -0.1 & 0.2 & 0.4 & 0.5 \\ \mathrm{~W} / \mathrm{CPI} & 0.8 & 0.9 & 1.0 & 1.1 \\ \mathrm{Q}_{\mathrm{T}} & -1.9 & -1.9 & -1.8 & -1.6 \\ \mathrm{Q}_{\mathrm{N}} & 2.7 & 2.9 & 3.0 & 2.9\end{array}$

All variables are measured by their percentage change over base-case values, where in the base case, there is no domestic energy production. These estimates treat the emergence of the energy sector as a one-shot, unanticipated phenomenum in 1980 . 
Conclusions and Extensions

Our model of a dynamic perfect foresight equilibrium in a multi-sector open economy elaborates earlier findings concerning the Dutch disease. For instance, in the third simulation we see clearly that the net effect of the energy sector is to reduce long-run production of other tradeables, and to improve the economy's terms of trade on final goods. The first simulation demonstrates that the size of this effect depends on government budget policies concerning the redistribution of oil-tax revenues to the private sector.

There are three extensions to this work that seem very fruitful at this. point. Most importantly, the model must be more accurately parameterized to depict the behavioral relationships in the U.K. economy. As indicated earlier, this work is now being undertaken at Harvard by Mr. Louis Dicks-Mireaux. Second, a monetary sector and nominal and real price rigidities can be built into the present framework, along the lines of [3]. Important aspects of the U.K. adjustment process in recent years have involved the interaction of monetary and real phenomena. For example, the strong appreciation of the pound sterling in the late 1970 s has often been attributed to its role as a "petro-currency", and this appreciation has had a profound effect on the real economy .

Finally, a one-country model can be usefully embedded in a multi-country context allowing us to endogenize the world rate of interest, foreign prices, and foreign wealth. As pointed out in [8], the overall effects of higher oil prices are importantly determined by shifts in these "world" parameters, which have been held fixed in this study. 


\section{Footnotes}

1 There is a subtle point in determining the country's new budget line after the oil discovery. The discovery induces a capital inflow, and the economy moves down the Rybczynski line from $A$ to $G$. The initial capital stock is $K$, and after the shock the stock is $K+\Delta K$. Initially, GDP $=r^{*} K+w L ;$ now $G D P=$ $r^{*}(K+\angle K)+W L+P_{E} Q_{E}$. Whether the foreign capital comes in the form of rentals from abroad, or foreign direct investment, or domestic investment financed from abroad, there will be a service income outflow (each period) in the amount $r^{*} \Delta K$. Thus, GNP rises exactly by the value of oil production. The budget line, through $A B$, shifts to $D F$. 


\section{$\underline{\text { References }}$}

1. Bruno, M., "Adjustment and Structural Change under Supply Shocks," forthcoming Scandanavian Journal of Economics, 1982.

2. Bruno, M., and J. Sachs, "Input Price Shocks and the Slowdown in Economic Growth: Estimates for U.K. Manufacturing," presented at the Conference on Unemployment, Newnham College, Cambridge, July 1981.

3. Buiter, W.H., and D.D. Purvis, "Oil, Disinflation, and Export Competitiveness: A Model of the 'Dutch Disease'," in J. Bhandari and B. Putnam (eds.): The International Transmission of Economic Disturbances under Flexible Ex-change Rates, forthcoming, MIT Press, $19 \overline{81 .}$

4. Corden, W.M., and J.P. Neary, "Booming Sector and De-industrialization in a Small Open Economy," mimeo, 1980.

5. Fleming, J.S., "U.K. Macro-Policy Response to Oil Price Shocks of 1974-75 and 1979-80," presented at the International Seminar on Macroeconomics, Paris, June 1981, and forthcoming in the European Economic Review, 1982.

6. Forsyth, P.J., and J.A. Kay, "The Economic Implications of North Sea Oil Revenues," Journal of Fiscal Studies, 1, July, 1980, 1-28.

7. Neary, J.P., and D.D. Purvis, "Real Ad justment and Exchange Rate Dynamics," presented at the NBER Conference on Exchange Rates and International Macro-economics, Cambridge, Mass., 1981.

8. Sachs, J., "Energy Growth under Flexible Exchange Rates," NBER Working Paper No. 582, November 1980; also forthcoming in J. Bhandari and B. Putnam (eds.): The International Transmission of Economic Disturbances under Flexible Exchange Rates, forthcoming, MIT Press, 1981 .

9. van Wijnbergen, S., "Optimal Investment and Exchange Rate Management in Oil Exporting Countries: A Normative Analysis of the Dutch Disease," mimeo, Development Research Center, World Bank, 1981. 